\title{
Hadis Rasulullah Seputar Komunikasi Antarbudaya
}

\author{
Said Ahmad Sarhan Lubis \\ Universitas Muhammadiyah Sumatera Utara \\ e-mail: saidahmad@umsu.ac.id
}

\begin{abstract}
This paper intends to find out the hadiths about intercultural communication. Intercultural communication in essence can create harmony and togetherness. Besides that, they can also understand the differences between individuals. This also often happens in Indonesia, because Indonesia is a country that has a variety of cultures. And this difference must be supported, maintained and preserved. In addition, in essence, intercultural communication contains an intercultural dimension. In other words, the existence of intercultural communication has had a positive impact to make it easier to socialize and minimize misunderstandings. Communication is not only the knowledge learned in lecture classes. Even communication itself has actually been taught by the Creator, Allah SWT, through the Qur'an about how important communication is for humanity, especially Muslims. Lexically communication is the sending and receiving of messages or news between two or more people. So the message in question can be understood. Communication influences changes in behavior, ways of life, and values. Intercultural communication in an Islamic perspective is based on several emphases: 1. Religious: Habluminallah (Human-Allah relationship), 2. Social Value: Hablum Minannas (Human-Human Relations). So here Islam encourages its people so that religion does not always prioritize aspects of worship, but Islam also advocates social worship, such as paying attention to the fate of weak people.
\end{abstract}

Keywords: Intercultural Communication, Islam, Hadith, Social Value.

\begin{abstract}
Abstrak
Tulisan ini bermaksud untuk mengetahui hadits-hadits seputar komunikasi antarbudaya. Komunikasi antarbudaya pada hakikatnya dapat menciptakan keselarasan dan kebersamaan. Selain itu juga dapat saling memahami sisi-sisi perbedaan antar individu. Hal itu pun sering terjadi di Indonesia, karena Indonesia merupakan negeri yang memilik ragam budaya. Dan perbedaan inilah yang harus didukung, dipelihara dan dilestarikan. Selain itu, pada hakikatnya, komunikasi antarbudaya mengandung dimensi antar budaya. Dengan kata lain, adanya komunikasi antar budaya telah memberikan dampak positif untuk mempermudah bersosialisasi dan meminimalisir kesalahpahaman. Komunikasi tidak hanya ilmu yang dipelajari di kelas perkuliahan semata. Bahkan komunikasi sendiri sebenarnya telah diajarkan oleh Sang Pencipta, Allah SWT, melalui kitabnya Alquran tentang bagaimana pentingnya komunikasi bagi umat manusia, khususnya umat Islam. Secara leksikal komunikasi adalah pengiriman dan penerimaan pesan atau berita antara dua orang atau lebih. Sehingga pesan yang dimaksud dapat dipahami. Komunikasi mempengatuhi perubahan perilaku, cara
\end{abstract}


hidup kemasyarakatan, serta nilai-nilai yang ada. Komunikasi antar budaya dalam perspektif islam berdasarkan beberapa penekanan: 1. Religius : Habluminallah (Hubungan manusia dengan allah), 2. Nilai Sosial : Hablum Minannas (Hubungan Manusia dengan manusia). Jadi di sini Islam mendorong umatnya agar dalam beragama tidak selalu mementingkan aspek ibadah mahdhoh saja, akan tetapi Islam juga menganjurkan ibadah sosial, seperti memperhatikan nasib-nasib orang lemah.

Kata Kunci : Komunikasi Antarbudaya, Islam, Hadits, Nilai Sosial.

\section{Latar Belakang Masalah}

Ketika adanya komunikasi di antara orang-orang yang memiliki kebudayaan yang berbeda-beda, di situlah terjadinya komunikasi antarbudaya. Stewart L. Tubis mengatakan bahwa komunikasi antar budaya adalah komunikasi antara orang-orang yang berbeda budaya. Pernyataan ini beranggapan bahwa perbedaan cara hidup yang berkembang dan dianut oleh sekelompok orang serta berlangsung dari generasi ke generasi. (Liliweri: 2002)

Selain Stewart, Hamid Mowland juga berpendapat bahwa komunikasi antar budaya sebagai human flow across national boundaries. Asumsi tersebut merupakan sekelompok manusia yang menyebrangi lintas budaya. Seperti adanya keterlibatan suatu konferensi internasional di mana bangsa-bangsa dari berbagai negara berkumpul dan berkomunikasi satu sama lain. Dengan kata lain, komunikasi antarbudaya ini akan terjadi ketika adanya komunikasi antara orang-orang yang memiliki kebudayaan yang berbeda-beda demi mencapainya suatu tujuan komunikasi yang sama serta terjalin interaksi yang lancar pada hakekatnya. Sedangkan menurut para ahli yang lain ada yang berpendapat seperti Sitaram (1970) yang mengatakan bahwa komunikasi antarbudaya merupakan seni untuk memahami dan saling pengertian antara khalayak yang berbeda kebudayaan. Jandit (1998)

Berbeda halnya dengan Srnover dan Porter (1972) yang berpendapat bahwa komunikasi antarbudaya terjadi manakala bagian yang terlibat dalam kegiatan komunikasi tersebut mempunyai latar belakang budaya dan pengalaman yang berbeda. Latar 
belakang tersebut mencerminkan nilai yang dianut oleh kelompoknya berupa pengalaman, pengetahuan, dan nilai. Kemudian, Rich (1974) menyimpulkan bahwa komunikasi antarbudaya terjadi ketika orangorang yang berbeda kebudayaan dipertemukan. Sehingga, dapat ditarik kesimpulan, bahwa komunikasi antar budaya ini merupakan komunikasi yang terjadi ketika kedua orang atau lebih sedang proses berkomunikasi, untuk mencapai pemahaman, maupun pengertian yang terjadi di antara khalayak yang berbeda kebudayaan. Oleh karena itu, kegiatan inilah yang membawa keselarasan dalam berkomunikas i(Tubbs dan Moss 1996)

Hakikat dari komunikasi antarbudaya ini merupakan kegiatan yang terjadi dalam berkomunikasi setiap individu dengan individu lain. Baik dua orang bahkan lebih. Sehingga, terciptalah kemudahan dan pemahaman segala macam bentuk perbedaan yang ada. (Devito: 2010)

Komunikasi antarbudaya pada hakikatnya dapat menciptakan keselarasan dan kebersamaan. Selain itu juga dapat saling memahami sisi- sisi perbedaan antar individu. Hal itu pun sering terjadi di Indonesia, karena Indonesia merupakan negeri yang memilik ragam budaya. Dan perbedaan inilah yang harus didukung, dipelihara dan dilestarikan. Selain itu, pada hakikatnya, komunikasi antar budaya mengandung dimensi antar budaya. Dengan kata lain, adanya komunikasi antar budaya telah memberikan dampak positif untuk mempermudah bersosialisasi dan meminimalisir kesalahpahaman. Pada pembahasan tulisan ini akan menguraikan mengenai hadis komunikasi antar budaya.(Purwasito: 2003)

\section{Teks Hadis Tentang Komunikasi Antarbudaya}

1. Hadis Utama

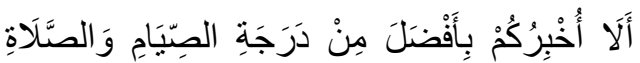

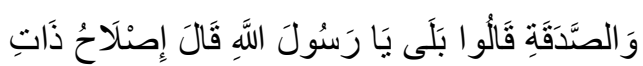

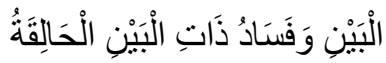

Artinya: "Maukah kalian saya beritahu suatu hal yang lebih utama daripada derajat puasa, shalat dan sedekah? Para sahabat menjawab: tentu ya Rasulallah. Lalu Nabi bersabda: hal tersebut adalah mendamaikan perselisihan, karena 
karakter perselisihan itu

membinasakan" (Al Hindi, 1985: 58)

2. Hadis hadis yang serupa

a. Hadis riwayat Imam Ahmad

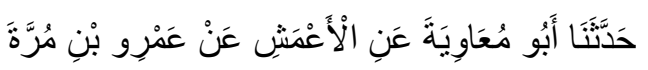

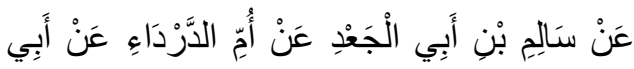

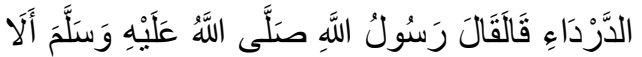

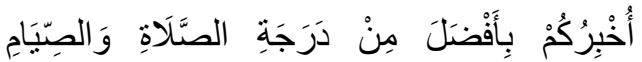

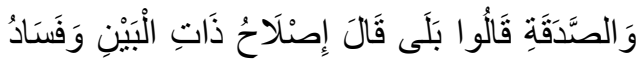
ذَاتِ الْبَيْنِ هِيَ الْحَالِقَةُ

b. Hadis riwayat Imam Bukhari حدثنا صدقة قال : حدثنا أبو معاوية ، عن الأعمش ، عن عمرو بن مرة ، عن سالم بن أبي الماله

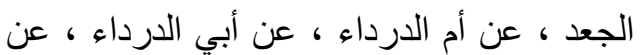

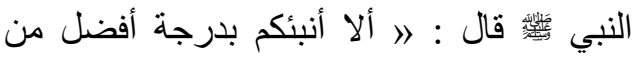
الصلاة والصيام و الصدقة ؟ « قالوا : بلى ، قال : " صلاح ذات البين (1) ، وفساد ذات البين هي لهي

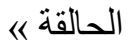

c. Hadis riwayat Imam Tirmidzi

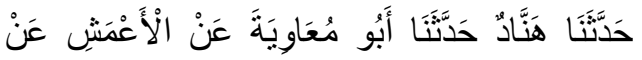

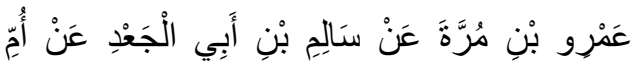

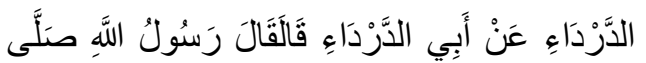

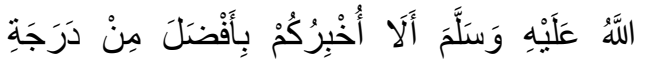

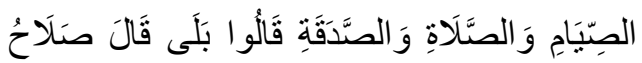

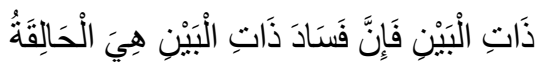

d. Hadis riwayat Imam Abu Daud

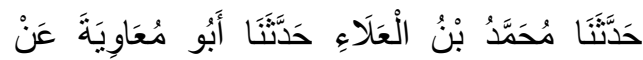

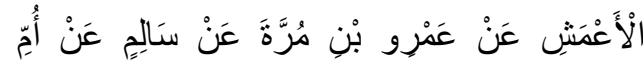

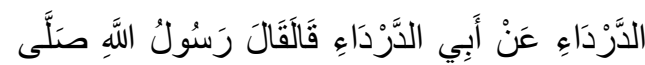

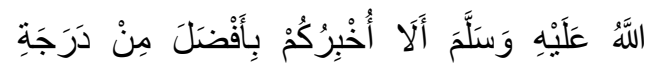

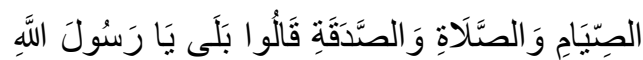

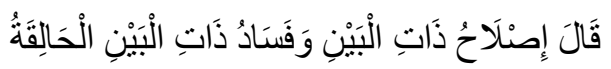

e. Hadis riwayat Ibnu Hibban أخبرنا عبد الله بن محم الأزدي ، قال : حدثنا إسحاق بن إبراهيم الحنظلي ، قال : حدثنا أبو

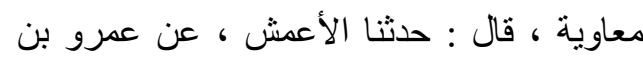

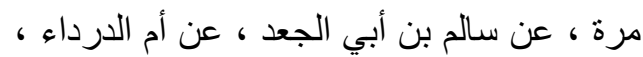
عن أبي الدرداء ، عن رسول الله صلى الله عليه وسلم قال : » ألا أخبركم ، بأفضل من درجة الصيام ، والقيام ؟ « ، قالو ا : بلى با رسول الله ، قال : 》 إصلاح ذات البين (1) ، وفساد ذات البين هي الحالقة « إن

f. Hadis riwayat Imam Baihaqy أخبرنا أبو الحسين بن الفضل القطان ، ببغداد ، أنا أبو عمرو بن السماك ح وأخبرنا أبو عبد الله الحافظ ، ثنا أبو العباس الأصم ، قالا : ثنا أحمد

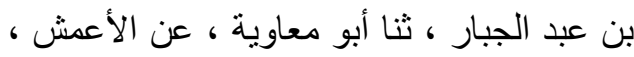

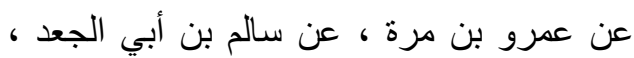

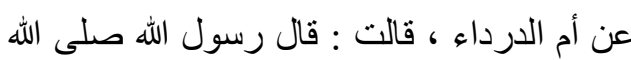
عليه وسلم : 》 ألا أخبركم بأفضل من درجة الصيام والصلاة والصدقة ؟ « قالوا : بلى يا رسول الله . قال : 》 صلاح ذات البين « ـ قال : 》 و وفساد ذات البين هي الحالقة 《) وفي رواية ابن السماك : 》 فإن فساد ذات البين هي الحالقة 《ي 


\section{Asbabul Wurud Hadis}

Asbabul wurud diartikan

dengan sebab-sebab keluarnya hadis, atau sebab-sebab yang menjadi pegantar Rasululullah Saw mengucapkan hadis. Untuk mengetahui asbab al-wurud Hadits perlu dilakukan penelitian dengan menggunakan kitab asbab al-wurud dan kitab syarah. Dan menurut penelitian penulis, hadits ini tidak ditemukan sebab wurud-nya. Adapun munasabah hadits ishlah ini dengan Alquran dan Hadits lain diantaranya adalah nash yang berbicara seputar perintah untuk berpegang teguh terhadap ajaran agama Allah, hidup rukun, menjunjung tinggi nilai persaudaraan, persatuan dan kesatuan tanpa permusuhan sebagaimana difirmankan oleh Allah Swt dalam Alquran surat Ali Imran ayat 103 :

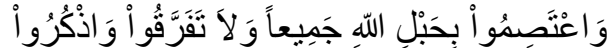

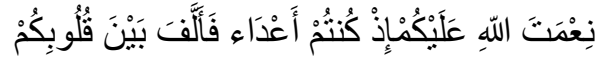

$$
\begin{aligned}
& \text { فَأَصْبَحْتُمُ بِنِعْمَتِهِ إِخْوَ انَاً }
\end{aligned}
$$

Artinya: "Dan berpegang teguhlah kalian semua kepada tali agama Allah, dan janganlah kalian bercerai berai, dan ingatlah akan nikmat Allah kepadamu, ketika kamu dahulu (masa jahiliyah) bermusuh-musuhan, maka Allah mempersatukan hatimu, lalu dengan nikmat-Nya kalian menjadi bersaudara"

Konsep ini merupakan salah satu ajaran agama Islam. Dalam Alquran terdapat beberapa ayat yang menerangkan tentang konsep tersebut, baik dalam kontek konflik level komunitas kecil seperti konflik yang terjadi dalam hubungan suami istri (Surat al-Nisa' ayat 128), maupun dalam level komunitas besar seperti konflik yang terjadi antara dua kelompok orang mukmin yang bertika (Surat al-Hujarat ayat 9).

Di dalam Hadits lainnya, disebutkan bahwa Abu Hurairah ra. berkata, Rasulullah saw. bersabda (yang artinya), "Setiap ruas tulang tubuh manusia wajib dikeluarkan shadaqahnya setiap hari ketika matahari terbit. Mendamaikan secara adil dua orang yang bertikai adalah shadaqah, membantu orang lain menaiki kendaraan atau mengangkatkan barang ke atas kendaraannya adalah shadaqah, katakata yang baik adalah shaqadah, tiaptiap langkah untuk mengerjakan shalat di masjid adalah shadaqah, dan menyingkirkan duri dari jalan adalah 
shadaqah." (HR. al-Bukhari dan Muslim)

\section{Hasil dan Pembahasan}

\section{Analisis Hadis}

\section{Berdasarkan Jumlah Rawi}

Menurut jumlah rawi, Hadits terbagi kepada Hadits mutawatir dan ahad. Hadits mutawatir adalah Hadits yang jumlah rawinya banyak dengan syarat beritanya mahshus (indrawi), tidak ada kesan dusta, dan tiap thabaqah jumlah rawi minimal empat orang. Hadits ahad adalah Hadits yang jumlah rawinya tidak banyak, yakni tiga setiap thabaqah (masyhur), dua setiap thabaqah (aziz), dan satu setiap thabaqah (gharib). Berdasarkan kriteria tersebut, maka Hadits tentang Ishlah termasuk Hadits Ahad Gharib sebab tidak memenuhi syarat mutawatir yakni setiap thabaqah jumlah rawinya minimal lima

\section{Berdasarkan Matan}

Dari segi bentuk matan, Hadits terbagi kepada Hadits qauli (ucapan), Hadits fi'li (perbuatan), dan Hadits taqriri (ketetapan). Dari segi idhafah matan, Hadits terbagi pada marfu' (idhafah pada Nabi), mauquf, dan maqthu. Dan apabila tanda bentuk dan idhafahnya eksplisit disebut haqiqi, dan jika implisit disebut hukmi. Berdasarkan ketentuan tersebut maka Hadits ini termasuk Hadits marfu', qauli, dan haqiqi. Marfu' artinya Hadits tersebut idhafahnya disandarkan langsung pada Nabi Saw. Qauli artinya adalah Hadits yang merupakan perkataan Nabi Saw. Adapun haqiqi adalah Hadits yang tanda bentuk dan idhafahnya eksplisit sabda Rasul Saw.

\section{Berdasarkan Sanad}

Dari segi bersambung tidaknya sanad, Hadits terbagi ke dalam muttashil dan munfashil. Hadits muttashil adalah Hadits yang sanadnya bersambung, yakni rawi murid dan rawi guru yang ada pada sanad bertemu (liqa') karena hidup sejaman, setempat, dan seprofesi Hadits. Hadits munfashil adalah Hadits yang sanadnya terputus (inqitha') yakni putus pada rawi pertama (mursal), putus pada mudawin dengan gurunya (mu'alaq), putus satu rawi dalam sembarang thabaqah (munqathi), dan putus dua rawi dalam dua thabaqah berturut- 
turut (mu'dhal). Berdasarkan kriteria tersebut, Hadits Ishlah adalah Hadits muttashil karena semua thabaqah mulai shahabat sampai mudawinnya bersambung.

Dari segi keadaan sanad, Hadits terbagi kepada Hadits mu'an'an (terdapat 'an dalam sanad), Hadits mu'anan (terdapat 'ana ta'kid dalam sanad), Hadits aliy (jumlah rawi dalam sanad sedikit dengan rata-rata per thabaqah-nya satu atau dua orang), Hadits nazil (jumlah rawi dalam sanad banyak dengan rata-rata per thabaqah-nya tiga orang atau lebih), Hadits musalsal (ada persamaan sifat rawi dalam sanad), dan Hadits muddabaz (ada dua rawi dalam sanad yang saling meriwayatkan). Berdasarkan kriteria tersebut, Hadits ini bisa dikatakan Hadits Mu'an'an dan Hadits Aliy.

\section{Kualitas Hadits}

\section{a. Tash-hih}

Berdasarkan kualitasnya, Hadits terbagi ke dalam Hadits maqbul dan mardud. Makbul adalah Hadits yang diterima sebagai hujjah dengan sebutan shahih dan hasan. Hadits mardud adalah Hadits yang ditolak sebagai hujjah dengan sebutan Hadits dh'aif. Hadits shahih adalah Hadits yang diriwayatkan oleh rawi yang tsiqah, sanadnya muttashil (liqa'), matannya marfu' (idhafah pada Nabi), tidak ada illat (penambahan pengurangan dan penggantian), dan tidak ada kejanggalan (tidak bertentangan dengan al-Qur'an, Hadits shahih, dan akal sehat). Hadits hasan sama seperti Hadits shahih namun rawinya tidak sampai tamm dhabit, tetapi hanya sampai qalil dhabit. Hadits dha'if adalah Hadits yang gugur satu syarat atau lebih dari syarat Hadits shahih atau hasan. Kaidah tersebut adalah kaidah dasar. Dalam tash-hih terdapat kaidah dalam kenaikkan kualitas, yaitu Hadits hasan dapat menjadi shahih apabila dikuatkan dengan muttabi' (sanad lain) dan syahid (matan lain), yang kemudian disebut shahih li ghairihi. Begitu juga Hadits dha'if yang mardud (ditolak sebagai hujjah) dapat naik menjadi makbul yakni menjadi hasan li ghairihi apabila Hadits dha'if tersebut memiliki muttabi' dan atau syahid, sepanjang dha'if-nya bukan maudhu', matruk dan munkar. 
Berdasarkan kaidah tersebut,

Hadits Ishlah dapat disimpulkan merupakan Hadits makbul dengan kategori shahih, karena diriwayatkan oleh rawi yang tsiqah, sanadnya muttashil (liqa'), matannya marfu' (idhafah pada Nabi), tidak ada illat (penambahan pengurangan dan penggantian), dan tidak ada kejanggalan (tidak bertentangan dengan al-Qur'an, Hadits shahih, dan akal sehat).Adapun keberadaan seorang rawi' yang dha 'if pada satu jalur periwayatan (dalam riwayat alBaihaqi) tidak mempengaruhi kualitas hadits secara keseluruhan.

\section{b. I'tibar}

Menentukan kualitas Hadits berdasarkan petunjuk jenis kitabnya (konvensi muhaditsin bahwa jenis kitab Hadits menjelaskan kualitas Haditsnya), penjelasan kitab kamus dan syarah, dan pembahsan kitab ilmu. Dengan i'tibar diwan dapat diketahui status Hadits Ishlah merupakan Hadits shahih karena terdapat dalam beberapa kitab shahih seperti Shahih Bukhari dan Ibnu Hiban, meski sebagiannya terdapat dalam kitab sunan.

\section{c. Tathbiq Hadits}

Setelah diketahui keshahihan Hadits ini, perlu untuk ditelusuri pada aspek penerapannya karena Hadits makbul mungkin ma'mul bih dan mungkin ghair ma'mul bih. Kaidahnya adalah sebagai berikut:

1. Jika Hadits makbul itu hanya satu atau banyak namun sama (baik lafzhi maupun ma'nawi), maka ma'mul atau ghair ma'mulnya ditentukan oleh muhkam atau mutasyabih-nya matan. Jika muhkam (lafazh dan maknanya jelas dan tegas) maka ma'mul bih. Namun jika mutasyabih (lafazh dan maknanya tidak jelas) maka ghair ma'mul bih.

2. Jika makbul itu banyak namun tanaqudh (berbeda) atau ta'arudh (berlawanan) maka untuk menentukan ma'mul dan ghair ma'mul-nya harus ditempuh terlebih dahulu dengan thariqah jama, kemudian tarjih, nasakh, dan tawaquf. Jika Hadits makbul itu yang ta'arudh bisa dikompromikan maka keduanya diamalkan dan disebut Hadits mukhltalif. 
Setelah ditarjih, maka yang unggul diamalkan (rajih) dan tidak unggul tidak diamalkan (marjuh). Dengan nasakh, maka yang wurud belakangan diamalkan (disebut nasikh) dan yang wurud duluan tidak diamalkan (disebut mansukh). Jika tidak bisa di-jama', tarjih, dan nasakh, maka di-tawaqufkan (mutawaqaff), artinya tidak diamalkan.

Berdasarkan kaidah di atas, maka Hadits ini merupakan Hadits makbul yang ma'mul bih, karena banyaknya lafazh matan Hadits yang sama (baik lafzhi maupun ma'nawi), yang semuanya lafazh-nya muhkam (lafazh dan maknanya

\section{Penjelasan Hadis dengan Ilmu Komunikasi}

Komunikasi tidak hanya ilmu yang dipelajari di kelas perkuliahan semata. Bahkan komunikasi sendiri sebenarnya telah diajarkan oleh Sang Pencipta, Allah SWT, melalui kitabnya Alquran tentang bagaimana pentingnya komunikasi bagi umat manusia, khususnya umat Islam. Secara leksikal komunikasi adalah pengiriman dan penerimaan pesan atau berita antara dua orang atau lebih. Sehingga pesan yang dimaksud dapat dipahami. Komunikasi mempengatuhi perubahan perilaku, cara hidup kemasyarakatan, serta nilai-nilai yang ada. Perubahan-perubahan tersebut tampaknya berbanding lurus dengan perkembangan teknologi komunikasi.

Efektifitas komunikasi menyangkut kontak sosial manusia dalam masyarakat. Ini berarti, kontak dilakukan dengan cara yang berbedabeda. Kontak yang paling menonjol dikaitkan dengan perilaku. Selain itu, masalah yang menonjol dalam proses komunikasi adalah perbandingan antara pesan yang disampaikan dengan pesan yang diterima. Informasi yang disampaikan tidak hanya tergantung kepada jumlah (besar atau kecil) akan tetapi sangat tergantung pada sejauh mana informasi itu dapat dimengerti atau tidak. Tujuannya adalah bagaimana mewujudkan komunikasi yang efektif dan efisien.

Dalam perspektif Islam, komunikasi disamping untuk mewujudkan hubungan secara vertical dengan Allah Swt, juga 
untuk menegakkan komunikasi secara horizontal terhadap sesama manusia. Komunikasi dengan Allah Swt tercermin melalui ibadah-ibadah fardhu (salat, puasa, zakat dan haji) yang bertujuan untuk membentuk takwa. Sedangkan komunikasi dengan sesama manusia terwujud melalui penekanan hubungan sosial yang disebut muamalah, yang tercermin dalam semua aspek kehidupan manusia, seperti sosial, budaya, politik, ekonomi, seni dan sebagainya.

Soal cara (kaifiyah), dalam Al-Quran dan Al-Hadits ditemukan berbagai panduan agar komunikasi berjalan dengan baik dan efektif. Kita dapat mengistilahkannya sebagai kaidah, prinsip, atau etika berkomunikasi dalam perspektif Islam. Kaidah, prinsip, atau etika komunikasi Islam ini merupakan panduan bagi kaum Muslim dalam melakukan komunikasi, baik dalam komunikasi intrapersonal, interpersonal dalam pergaulan sehari hari, berdakwah secara lisan dan tulisan, maupun dalam aktivitas lain.

Dalam berbagai literatur tentang komunikasi Islam kita dapat menemukan setidaknya enam jenis gaya bicara atau pembicaraan (qaulan) yang dikategorikan sebagai kaidah, prinsip, atau etika komunikasi Islam, yakni (1) Qaulan Sadida, (2) Qaulan Baligha, (3) Qulan Ma'rufa, (4) Qaulan Karima, (5) Qaulan Layinan, dan (6) Qaulan Maysura.

Komunikasi antar budaya dalam perspektif Islam berdasarkan beberapa penekanan:

1. Religius : Habluminallah (Hubungan manusia dengan allah)

2. Nilai Sosial : Hablum Minannas (Hubungan Manusia dengan manusia).

Islam memiliki ajaran yang membentangkan dua bentuk hubungan yang harmonis

a. Tata hubungan yang mengatur antara manusia dengan Tuhannya dalam hal ibadah (ubudiyah) atau yang populer dikatakan dengan hablum minallah

b. Tata hubungan yang mengatur antara manusia dengan makhluk yang lainnya dalam wujud amaliyah sosial. Dalam Alquran surat Ali Imron: 112 Allah swt berfirman 


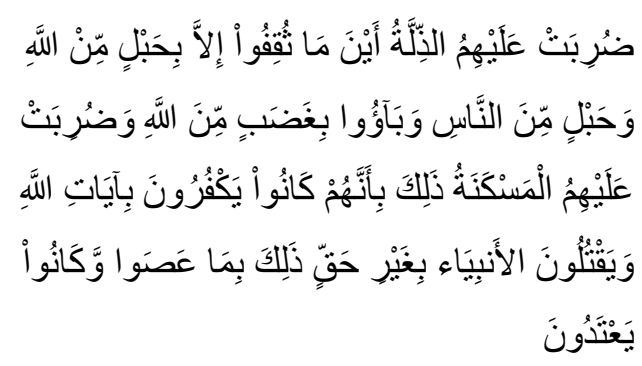

Artinya:"Mereka diliputi kehinaan di mana saja mereka berada, kecuali jika mereka berpegang kepada tali (agama) Allah dan tali (perjanjian) dengan manusia dan mereka kembali mendapat kemurkaan dari Allah dan mereka diliputi kerendahan. yang demikian itu karena mereka kafir kepada ayat-ayat Allah dan membunuh Para Nabi tanpa alasan yang benar. yang demikian itu disebabkan mereka durhaka dan melampaui batas."

Ayat ini memberikan kepada kita tentang malapetaka yang telah menimpa Bani Israil sebagai akibat kedurhakaan mereka kepada Allah dan kepada para nabi. Sehingga mereka harus mengalami malapetaka, kehinaan, kemiskinan, dan kemurkaan dari Allah. Dan dalam ayat tersebut diberitakan pula bahwa jalan keluar dari segala malapetaka tersebut adalah membangun kembali hablum minallah dan hablum minannas.
Hablum minallah menurut bahasa berarti hubungan dengan Allah. Namun dalam pengertian syariah makna hablum minallah sebagaimana yang dijelaskan di dalam tafsir At-Thabari, AlBaghawi, dan tafsir Ibnu Katsir adalah "Perjanjian dari Allah, maksudnya adalah masuk Islam atau beriman dengan Islam sebagai jaminan keselamatan bagi mereka di dunia dan di akhirat" Sehingga dapat kita pahami bahwa untuk membangun hubungan kita kepada Allah, kita mempunyai kewajiban untuk menunaikan hak-hak Allah, dan apakah hak-hak Allah itu? Hakhak Allah ialah mentauhidkan dan tidak menyekutukan-Nya dengan yang lain serta menjalankan syariat Allah. Misalnya: sholat, puasa dan sebagainya. (Daud Ali: 1998)

Namun apakah cukup hanya dengan hablum minallah saja, sedangkan di sisi yang lain kita mengabaikan hablum minannas? Tentu tidak cukup, mengingat kita adalah makhluk sosial yang tidak bisa hidup tanpa bantuan orang lain. Di dalam Alquran juga banyak ayatayat yang menyebutkan tentang perintah mengerjakan sesuatu yang 
berkaitan dengan hablum minannallah namun diiringi juga dengan hablum minannas, antara lain pada QS.Al-Ma'arij ayat 19-24 yang artinya:

"Sesungguhnya manusia diciptakan bersifat keluh kesah lagi kikir (19), Apabila ia ditimpa kesusahan ia berkeluh kesah (20), Dan apabila ia mendapat kebaikan ia amat kikir (21), Kecuali orang-orang yang mengerjakan shalat (22), Yang mereka itu tetap mengerjakan shalatnya (23), Dan orang-orang yang dalam hartanya tersedia bagian tertentu (24), Bagi orang (miskin) yang meminta dan orang yang tidak mempunyai apa-apa (yang tidak mau meminta)" (DEPAG RI: 2002)

Dalam ayat tersebut secara tegas Allah menyebutkan bahwa keluh kesah dan kikir itu telah menjadi sifat bawaan manusia sejak dia diciptakan. Bukankah kalau kita tidak memiliki harta kita sering berkeluh kesah? Sebaliknya, kalau kita memiliki banyak harta kita sering lebih cenderung untuk kikir. Lalu bagaimana caranya agar sifat bawaan kita tersebut dapat kita hindari? Allah menyebutkan paling tidak ada dua jalan, pertama, mengerjakan sembahyang (hablum minallah) secara kontinu. Kedua, menyadari bahwa dalam harta yang kita miliki terkandung bagian tertentu untuk fakir miskin (hablum minannas).

$$
\text { Di dalam Al-Quran Allah }
$$
berfirman di dalam surat an-nisa ayat 36 yang berbunyi

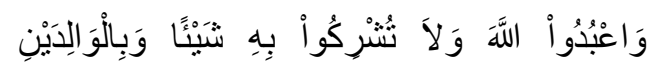

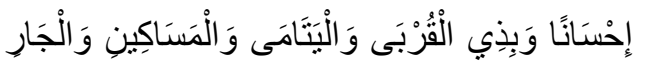

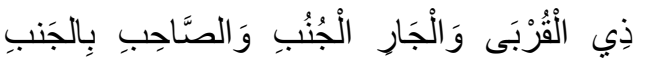

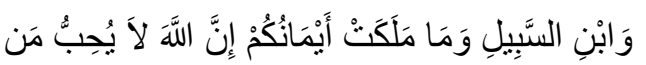
كَانَ مُخْنَالَا فَخُورًا Artinya: "Sembahlah Allah dan janganlah kamu mempersekutukanNya dengan sesuatupun. dan berbuat baiklah kepada dua orang ibubapak, karib-kerabat, anak-anak yatim, orang-orang miskin, tetangga yang dekat dan tetangga yang jauh, dan teman sejawat, Ibnu sabil dan hamba sahayamu. Sesungguhnya Allah tidak menyukai orang-orang yang sombong dan membanggabanggakan diri"

Ayat tersebut mengandung dua bentuk akhlak, yaitu akhlak kepada Allah (hablum minallah) yang ditunjukkan dengan perintah agar kita menjalin hubungan baik kepada Allah dengan cara tidak 
menyekutukan-Nya dengan yang lain. Dan akhlak terhadap sesama manusia (hablum minannas) yang ditunjukkan dengan perintah berbuat baik kepada kedua orang tua, karib kerabat, anak-anak yatim, orangorang miskin tetangga yang dekat dan tetangga yang jauh, teman sejawat, orang yang dalam perjalanan dan hamba sahaya.

Selanjutnya Allah menutup ayat di atas dengan kalimat: " Sesungguhnya Allah tidak menyukai orang-orang yang sombong dan membangga-banggakan diri". Dengan maksud agar kita tidak sombong kepada orang tua, karena ada saat dimana kita juga pasti akan menjadi tua. Jangan sombong kepada anak-anak yatim karena ada saat kita juga akan menjadi yatim. Jangan sombong kepada orang miskin karena ada saat kita juga akan menjadi miskin secara tiba-tiba. Jangan sombong kepada tetangga karena merekalah orang yang pertama memberikan pertolongan kepada kita saat kita mengalami kesulitan. Jangan sombong kepada teman karena kita sangat membutuhkannya. Jangan sombong kepada musaffir karena ada saat dimana kitapun akan menjadi musafir dan jangan sombong kepada pembantu rumah tangga karena mereka besar bantuannya kepada kita meskipun tidak besar upah yang kita berikan.

Dalam surat Al-Ma'un ayat 17 Allah berfirman:

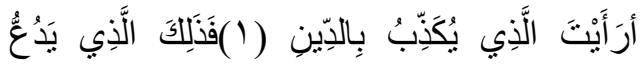

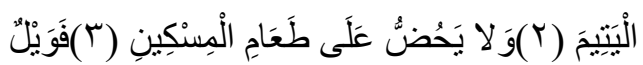

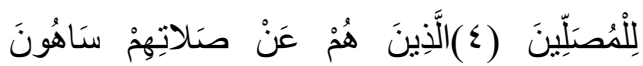

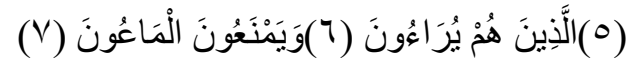
Artinya:"Tahukah kamu (orang) yang mendustakan agama? (1), Itulah orang yang menghardik anak yatim(2), Dan tidak menganjurkan memberi makan orang miskin (3). Maka kecelakaanlah bagi orangorang yang shalat (4), (yaitu) orangorang yang lalai dari shalatnya (5), Orang-orang yang berbuat riya (6), Dan enggan (menolong dengan) barang berguna (7)"

Dalam surat tersebut, Allah SWT demikian lugas mengaitkan antara agama dengan keberpihakan kepada kaum dhuafa. Seseorang dikategorikan mendustakan agama manakala ia mengabaikan anak yatim dan orang miskin. Di awal surat AlMa'un tersebut Allah menggunakan pertanyaan, tapi bukan berarti Allah 
bertanya karena tidak tahu. Menurut para mufassir hal itu dimaksudkan untuk menggugah hati pendengarnya agar memberikan perhatian lebih kepada ayat selanjutnya.

\section{Penutup}

Jadi di sini Islam mendorong umatnya agar dalam beragama tidak selalu mementingkan aspek ibadah mahdhoh saja, akan tetapi Islam juga menganjurkan ibadah sosial, seperti memperhatikan nasib-nasib orang lemah. Bahkan kalau kita cermati 5 rukun Islam itu adalah merupakan gabungan antara habluminallah dan hablum minannas, gabungan antara hubungan vertikal dan horizontal. Dimulai dari mengucapkan dua kalimat syahadat yang merupakan pertalian antara seorang hamba dengan Allah, namun pengakuan dan kesaksian tersebut tidaklah cukup tanpa terus menerus menjaga hubungan baik dengan Allah, yaitu dengan melaksanakan shalat sebagai rukun Islam yang kedua. Shalat yang secara simbolis gerak-geriknya mencerminkan kepasrahan kita kepada Allah. Kemudian ketaatan tesebut dibuktikan dengan mengerjakan amaliah sosial yaitu zakat sebagai rukun Islam ke-3. Kemudian dalam rukun Islam yang ke4 yaitu puasa, kita dilarang makan dan minum sebagai pelajaran bagi kita untuk dapat merasakan bagaimana rasanya ketika seseorang tidak bisa makan dan minum.

Dalam sebuah hadits qudsi dikatakan bahwa pada hari kiamat nanti Allah akan berfirman: "Wahai anak Adam,...Aku meminta makan kepadamu tapi engkau tidak memberiku makan." $\mathrm{Si}$ hamba bertanya, "wahai Tuhanku.... bagaimana mungkin aku memberMu makan sedangkan Engkau adalah Tuhan semesta alam?" Allah berfirman, "tidakkah kau tahu bahwa hamba-Ku si fulan meminta makan kepadamu tapi engkau tiada memberinya makan? Tidakkah engkau tahu bahwa jika engkau memberinya makan, niscaya engkau akan menemukan itu disisi-Ku.

"Wahai anak Adam,... Aku meminta minum kepadamu tapi engkau tidak member-Ku minum." si hamba menjawab, "wahai Tuhanku, bagaimana mungkin aku member$\mathrm{Mu}$ minum sedangkan Engkau adalah Tuhan semesta alam." Allah berfirman, "hamba-Ku si fulan 
meminta minum kepadamu tapi engkau tiada memberinya minum. Padahal jika engkau memberinya minum niscaya akan kau dapati itu disisi-Ku". (Taufik dkk, 2010)

Hadits tersebut secara tidak langsung memerintahkan kita untuk peka terhadap fenomena sosial. Apakah kita sudah memperhatikan orang-orang yang sedang membutuhkan pertolongan kita baik berupa makanan, minuman, dll ataukah kita termasuk orang yang terlena dengan gemerlap dunia sehingga melupakan hal itu? Amat banyak kehidupan orang lain di sekitar kita yang tidak memiliki kehidupan seberuntung kita. Seburuk apapun kondisi kita saat ini, pasti masih ada saja yang lebih buruk dibandingkan dengan kehidupan kita sekarang. Kita lihat sekarang saudara-saudara kita yang ada di Palestina sana, mereka sedang membutuhkan bantuan kemanusiaan dari seluruh ummat Islam dunia, tak terkecuali bantuan kita ummat Islam indonesia. Cukupklah ayat-ayat dan hadits tersebut sebagai penggugah hati kita untuk peduli terhadap saudara-saudara kita yang sedang membutuhkan bantuan kita.

\section{Daftar Pustaka}

Ali, Mohammad Daud. 1998. Pendidikan Agama Islam. Rajawali pers: Jakarata.

al-Hindiy, Al-Muttaqiy. 1985. Kanz al-'Ummal fi Sunan al-Aqwal wa al-Af'al. Mausu'ah alRisalah: Beirut.

Al-Suyuthi. 1988. al-Jami' alShaghir. al-Maktabah alIslamiy: Beirut.

Depag. RI. 2002. alquran Terjemah. Gema Insani Perss: Jakarta.

Devito, Joseph A. 2010. Komunikasi Antarmanusia. Kuliah Dasar. Professional Books: Jakarta.

Fred E. Jandt. 1998. Intercultural Communication, An Introduction. Sage Publication: London.

Liliweri, Alo. 2003. Dasar-Dasar Komunikasi Antarbudaya. Pustaka Pelajar: Yogyakarta.

Purwasito, Andrik. 2003.Komunikasi Multikultural. Universitas Muhammadiyah Surakarta: Surakarta.

Stewart L. Tubbs dan Sylvia Moss. 1996. Human Communication: Konteks-konteks Komunikasi. Remaja Rosdakarya: Bandung.

Taufik, Ahmad dkk. 2010. Pendidikan Agama Islam. Yuma Pustaka: Surakarta.

Wensinck, A.J. 1946. al-Mu jam alMufahras li Alfazh al-Hadits al-Nabawiy. Maktabah Baril: Beirut. 